\title{
Hospitality and Leisure between Religious Maxims and Modern Facilities
}

\author{
Abdi O. Shuriye PhD \\ Mohd Radzi Haji Che Daud PhD
}

International Islamic University, Malaysia

\section{Doi:10.5901/mjss.2014.v5n27p1127}

\begin{abstract}
The word host means stranger or enemy in it is Latin origin and hospitem stands for guest in Latin. The English language therefore derives various words from this origin including hospital, host, hostel, hotel and hospitality. In our contemporary world there has been an increasing focus on Islamic services related to hospitality; and in fact, halal revolution has created awareness among Muslims in leisure and hospitality services and consumption. In order to cater for this demand hotels are becoming innovative in products, food, and services. Nonetheless, to synchronize religious maxims and modern facilities has never been an easy task for this industry. This paper is part of a major research on the concept of Halalan Tayibah as stipulated in the Qur'an. The aim of the research in its complete sense is to examine and illustrate several features and the characteristics of hospitality services offered in Islamic compliant hotels in Kuala Lumpur.
\end{abstract}

\section{Introduction}

Islam is an unadulterated and all-inclusive Deen (system of life) and touches all aspects of man's endeavour. The Qur'an contends: "...This day I have perfected for you your religion and completed Myfavor upon you and have approved for you Islam as religion..." (Al-Qur'an, al-Maidah: 3). In another related verse Allah reminds: "We have revealed to you the book which clarifies every matter"(Al-Qur'an, al-Nahl:89). Similar verse reads: "And there is no creature on [or within] the earth or bird that flies with its wings except [that they are] communities like you. We have not neglected in the Register a thing. Then unto their Lord they will be gathered.(Al-Qur'an, Al-An'am:38). Indeed Allah through Al-Qur'an commands the believers of righteousness and halal means of acquisitions in food, clothing, relationships, shelter, knowledge and everything about him. It reads: "O ye people! Eat of what is on earth, lawful and good; and do not follow the footsteps of the evil one, for he is to you an avowed enemy. Holy Quran, (Al-Qur'an, Al-Baqarah: 168).

The prophet (pbuh) also educated the Muslims to involve in good and pure activities and to be righteous. He further warned them to shun all unlawful ways, food and clothing "...Allah is good and accepts nothing but what is good .... Then he mentioned a man who had travelled on a long journey, his hair dishevelled and discoloured with dust. "He will raise his hands to the sky saying ' $O$ Lord! O Lord!' but his food is unlawful, his drink is unlawful, and his clothing is unlawful. Howthen can he be answered?" (Sahîh Muslim). Based on these instructions Muslims are very particular about halal means of life which bring about the concept of "halal food" adopted in many countries as well as the Middle East countries. (World Travel Market, 2007 as cited in Battour, Nazari et.al, 2010). This awareness extended from demandfor halal food to halal products and services and it is growing exponentially with globalization in place. This is evident and significant in finances and food both in the past and at present; this development which can be tagged halal revolution is moving in the direction of the tourism industry. .

\section{Halal Revolution}

Halal revolution can be defined as the application of halal concept to the way of life of people. This is can be said to said to come from the awareness of Muslims about their religion and obeying the commandment of Allah as earlier quoted in Al-Qur'an, Al-Baqarah: 168.

More consumers travelling and many more people choosing to live and work abroad, demand for halal products. Mohd Salleh, Othman \& Mohd Noor (2010 as cited in NorShahrulNizam\&NorzaidiDaud2012) observed a shift from tourism from Middle East to UK and US after Sept 11, 2000 to other Muslim countries such as Malaysia. Similar view was given by Henderson (2003 as cited in Battour, Nazari et.al, 2010) where he claims that the traditional Arab and Muslim 
choice of USA and Europe destinations has changed since the September 11 attacks with Middle Eastern and hence, Muslim countries becoming increasingly popular destinations for Muslim tourists. The work of Sahida, Ab Rahman, Awang, \& Che Man (2011) confirms the rapid growth in the tourism and hospitality industry. Sahida et al.(2011)wrote:

\begin{abstract}
"Meanwhile the tourism and hospitality industry have shown a rapid growth in generating large income and opportunities in many countries. According to World Tourism Organization (WTO), the international tourism receipts are estimated to reach US\$ 919 billion worldwide in 2010, an increase from US\$ 851 billion in 2009. Furthermore, international tourist arrivals grew by nearly 7\% in 2010 to 940 million. Metelka (1990, p. 73)" Sahida et al.(2011)
\end{abstract}

The numerous products and services offered in the tourism industry includes accommodation, food services,transportation, place of attractions and other related sectors to the hospitality service (Sahida et al., 2011). Therefore Muslim tourists prefer halal hospitality.

\title{
3. Hospitality and Islam
}

The oxford English Dictionary defined hospitality as "the reception and entertainment of guests, visitors or strangers with liberality and good will". Barrows \& Powers (2009) described the word as being derived from "hospice", a term used for a medieval place of rest for travellers and pilgrims. He continues: "Hospice - a word that is clearly related to hospital -also referred to an early form of what we now call a nursing home". The same work explains further by citing the different areas of coverage of the term to include hotels, restaurants and institutions that provide either lodging, food, or both to individuals away from their homes. Hence, Barrows \& Powers (2009) concluded that hospitality definition can be expanded"to include those institutions that provide other types of services to people away from home such as private clubs, casinos, resorts, attractions, and so on".

Brotherton (1999, as cited in Lashley, Lynch, \& Morrison, 2007) defined hospitality as "a contemporaneous human exchange, which is voluntarily entered into, and designed to enhance the mutual well-being of the parties concerned through the provision of accommodation, and/or food and/or drink". The work of Morrison and O'Gorman (2006, as cited in Lashley, Lynch, \& Morrison, 2007) offered a multifaceted definition as hospitality was defined as thus:

\begin{abstract}
"It represents a host's reception, welcome and entertainment of guests or strangers of diverse social backgrounds and cultures charitably, socially or commercially with the kind and generous liberally, into one's space to dine and/or lodge temporarily. Dependent on circumstance and context the degree to which the hospitality offering is conditional or unconditional".
\end{abstract}

Lashley (2000) believed that the diverse definitions of hospitality activities made it more interesting due to the fact they confirm its recent preoccupation with commercial provision. He presented the definitions of hospitality as given by the Joint Hospitality Industry Congress (JHIC) and the Higher Education Funding Council (HEFC). The latter defines hospitality as "the provision of food/or drink and/or accommodation in a service context" while the former describes the term as "the provision of food and/or drink and/or accommodation away from home". Calvo(2013) wrote when describing hospitality:

\footnotetext{
"The fungible language of hospitality and its related concepts - hospital, hostel, hotel, hospice - resonates in the popular images and political discourse of immigration, and in the newly-minted promotional media of the hospitality industry. It also reverberates in the places of welcome and care suggested by its Latin root, hospitium: the hospitals and hospices" ... "the practice of hospitality (xenia, hospitium) was one of the most cherished virtues in ancient Greece and Rome. Hospitiuminitially signified the simple but sacred duty of every man to welcome and protect any stranger. It later became a formal agreement of mutual aid between two persons and their families". (Calvo, 2013)
}

Using the study of Nybakken (1946) as basis, two types of hospitality were identified when the term was extended to include agreements between an individual and a community and between statesand nations. The two types he named hospitiumprivatum (private hospitality) which is established between individuals, and hospitumpublicum (public hospitality) which exists between two states.

However, Heal (as cited in O'Connor, 2005) believed that the hospitality is now more important in the commercial domain and diminished in other spheres. He argues:

"five basic principles have governed English hospitality during the last few centuries. These he stated 
i. That the relationship between host and guest is a natural one (i.e. that it is grounded in the nature of social life).

ii. That an intrinsic part of being a host is having regard for the sacred nature of the guest (which refers to the honour and status the guest may bring to the host).

iii. That hospitality is noble.

iv. That selfless giving is an established and expected part of English social life.

v. That hospitality, and the social relationships and exchanges it engenders are at least as important as those formed in the market place".(O'Connor, 2005)

Khan(2012) comparing the present perception of hospitality between host and the guest wrote: "the best guest is one, who does not burden the host. Failing to give a prior notice, visiting at inappropriate times, prolonging ones stay and burdening the host with expectations, on how one should be treated, disgruntle a host in our eastern civilization". He wrote about the other extreme which he asserted was the attitude in the western world:

"A guest must be prepared to depend as much as possible on himself, and might, occasionally, meet his host at breakfast, or may be dinner or any other time, when their schedules coordinate. For the visitor this may mean cooking for himself, doing his own laundry, taking the bus for errands or sightseeing, etc. The bottom-line is that the guest seeks his own comfort and thanks the host profusely for all the boarding facilities that would otherwise have cost a fortune" (Khan, 2012)

Similarly, Meehan (2012) wrote: "the true concept of hospitality is not something that is widely practiced in most non-Muslim countries. For many non-Muslims, the entertainment of guests is of primary importance in many cases for worldly reasons only, not rooted in real hospitality for the sake of God".

However, Islam places great importance on the kind treatment and hospitality of guests and neighbours. Therefore her regard of hospitality as a great virtue that holds a noteworthy purpose. Based on this, Islam commands Muslims to be hospitable to neighbours and guests. Because this increases societal ties as well as unite the whole community.

Abu Hurairah (rta) reported the Prophet (sa) saying: "He, who believes in Allah (swt) and the Last Day, let him show hospitality to his guest..." (Bukhari and Muslim). Here hospitality is linked with faith. Hafiz Salahuddin Yusuf in his commentary in Riyad-us-Saliheen states: "To honour a guest means to welcome him cheerfully, entertain him happily, according to our capacity, and have full regard of his comfort and rest."

Relating the story of how prophet Ibrahim showed hospitality to his guest in order tolay a guideline on how to take care of our guests, Allah (swt), the Exalted, says:

Has the story reached you, of the honored guests of Abraham (as)?, 25) When they came in to him and said: "Peace be upon you!" He [Abraham] replied: "Peace be upon you," and said: "You are a people unknown to me." 26) Then he turned to his household secretly and brought out a fattened [roasted] calf. 27) Then placed it before them [noticing that they refrain from eating, he said]: "Will you not eat (Al-Qur'an, Adh-Dhariyat:24-27).

The above verses displayed how Ibrahim (as), entertained his guests. He knew they were stranger but then his still belief he has to show them hospitality for the fact that he sees them as human being. This is because he is endowed with this noble character. One of the ways of being kind to the visitors is in reciprocation of greeting. IbnKathir in his commentary said:

"When you are greeted with a greeting, greet in return with what is better than it, or return it equally.)(4:86) So the Friend of Allah chose a better reply in return for their greeting, implementing Allah's command: Reciprocating the greeting with the term Salamun is stronger than the greeting using the term Salaman..." (IbnKathir)

Another way is to accommodate and prepare a feast. Ibn Kathir wrote about the understanding of these verses and hospitality:

"(Saying, "Will you not eat") Ibrahim said this polite and kind statement to his guests, and surely, this Ayah indicates proper manners for honouring guests. For he brought the food to his guests quickly, while they were unaware that it was being prepared for them. He did not first mention this favor to them by saying, "We will make food for you." Rather, he discretely had it prepared and placed before them. He prepared the best kind of food he had, a young, fat roasted calf. He did not place the food far from them and invite them to come close to it to eat. Rather, he placed it close to them and refrained from ordering them to eat. Instead he invited them using a kind and subtle invitation". (Ibn Kathir)

Sayyid Qutb in his commentary of the Qur'an (In the Shade of Qur'an) wrote about these verses: 
"It describes Abraham's guests as honoured, either because they are so in God's sight, or because of how Abraham paid honour to them as we soon learn. Abraham's hospitality appears very clearly from the first moment his guests arrived. Once they greeted him and received his reply, and despite the fact that they are total strangers, he immediately goes to his wife telling her to prepare food. He provides a large quantity of food, sufficient for scores of people: "He turned quickly to his household and brought out a fat calf' (Verse 26) According to some reports, there were only three guests, which means that a shoulder of that calf would have been sufficient to give them a good meal" (Qutb)

Yusuf Ali in his commentary explains

"They seemed unusual strangers, but he said nothing and quietly proceeded to perform the rites of hospitality. He brought a roast fatted calf and placed it before them to eat. But the strangers did not eat (11:70).

This disconcerted him. According to the laws of hospitality, a stranger under your roof is under your protection, but if he refuses to eat, he refuses your hospitality and keeps himself free from any ties of guest and host".

This story can be regarded as a demonstration of hospitality at home for the host and at journey for the visitors. Hence, Hospitality in Islam has many features which cover diverse areas besides the hospitality shown to the home visiting guests. Meehan(2012) classified hospitality to include hospitality at home, in need and towards neighbours.

There are several traditions of the prophet emphasising the importance of hospitality and encouraging the Muslim to be hospitable. In one of those traditions the story of Abu Talha and his family was related by Abu hurayrah when Allah revealed a verse purposely because of his hospitable act. Abu Hurayrah relates:

"A man came to the Prophet and said, 'O Allah's Messenger! Poverty has stuck me.' The Prophet sent a messenger to his wives (to bring something for that man to eat) but they said that they had nothing. Then Allah's Messenger said: "Who will invite this person or entertain him as a guest tonight; may Allah grant His mercy to him who does so" An Ansari man said, 'I, O Allah's Messenger!' So he took him to his wife and said to her, 'Entertain the guest of Allah's Messenger generously.' She said, 'By Allah! We have nothing except the meal for my children.' He said, 'Let your children sleep if they ask for supper. Then turn off the lamp and we go to bed tonight while hungry.' She did what he asked her to do. In the morning the Ansari went to Allah's Messenger who said, (Allah wondered (favourably) or laughed at the action of so-and-so and his wife.) Then Allah revealed: "and they give them preference over themselves even though they were in need of that". ( Al-Bukhari, Muslim, At-Tirmidhi, and An-Nasa'i)

In another narration the Prophet (SAW) has also linked the practise of hospitality to guest and neighbour to the faith in His unity and the Day of Qiyamah. Abu Shuraih Khuwailid Bin Amr Al-Khuzai (rta) reported that he heard the Messenger of Allah (swt) (sa) saying:

"He, who believes in Allah (swt) and the Last Day, should accommodate his guest according to his right." He was asked: "What is his right, O Messenger of Allah (swt)?" He replied: "It is to accommodate him for a day and a night and extend hospitality for three days, and what is beyond that is considered charity." (Bukhari and Muslim)

On this hadith Khan(2012) comments and highlighted some relationships that should occur between the host and the guest. He wrote:

"This Hadeeth deals more with the etiquette and scope of hospitality. On the first day and night, a guest should be offered the best entertainment. In the next two days, hospitality should be moderate. On the fourth day, the guest should leave for his destination. Yet, if the guest chooses to stay, he should not expect formal hospitality but rather seek to be as dependent on himself as possible. If the host willingly entertains the guest after three days, it will be considered charity on his part.(Khan, 2012)

Conclusively, just like every other aspect of Islam, rules of hospitality are also driven by wisdom and courtesy. Islamic hospitality also include given food, drink, accommodation, best salutations, conversations and all that will make the guest to feel safe and comfortable. In addition, hospitality in Islam encompasses "having good manners and treating others with dignity and respect" (Meehan, 2012). Therefore Islam applied it to the greater community. It also includes kind treatment of a neighbour such as offering of tangible like food or gifts, and intangible thing like advice to him. This should be done with an open hand and not expect, or request, anything in return. Living in peace and tranquillity is another means of hospitality towards a neighbour. However, today man lives in communities with the belief that neighbours are enemies and they "engage in battles over things like property infringement and the like" (Meehan, 2012).

With Islamic awareness of living with halal mean of life, Muslims therefore finds solace in obedience of his Creators 
commandments through halal food, drink, accommodation and leisure. Hence, the need for an Islamic Compliant Hotel.

\section{Islamic Compliant Hotel}

The awareness among Muslims in leisure, hospitality services and consumption created by Halal revolution is producing an Islamic Hospitality or Shariah hotel. Md Salleh, Abdul Hamid, Hashim, \& Omain(2014) affirm:" recently, the existence of Islamic hospitality or Shariah hotel is being built beyond Gulf countries in Asia". He believed Shariah compliant hotel $(\mathrm{SCH})$ "is a new innovative and creative service" that is found in the hotel business. The concept he assumed evolved from fulfilling religious needs to lifestyle option with emphasis on family and health (Anonymous, 2009 as cited in Md Salleh, Abdul Hamid, Hashim, \& Omain 2014). However, Ramli (2009), described it as similar to the existing western hotels'. Henderson (2010)regarded the concept as an element of Islamic tourism because of the crucial need of accommodation by the tourists. The ICH is also known as the Shariah Compliant Hotel (SCH) (Razalli, Abdullah, \& Hassan, 2012). But this work will adopt ICH. The ICH (also SCH) was defined by Shamim (2009, as cited in Razalli et al., 2012; Sahida et al., 2011)as a hotel that provides services in accordance to the Shariah principles. Its operations are not limited to serving halal food and drink, but also encompasses making sure that all other entire operations are governed by Shariah principles.

The Islamic hotel according to Samori \& Abd Rahman (2013) lacks an established model and a formal criteria the Middle East (Samori \& Abd Rahman, 2013).Din (as cited in Salleh, Hamid, Hashim, \& Omain, 2014) in an attempt to describe an $\mathrm{ICH}$ proposed that such hotels could offer:

"prayer mat, Quran, and prayer beads; show the sign of Kiblah for the Muslim guest to perform a daily prayer; should ban alcohol; provide different utensils for Muslim customers; and be sensitive to the guest's religion by providing Quran for a Muslim or Bible for a Christian. Unmarried couples are not allowed to check in, which means that the hotel should request the marriage certificate upon checking in, and lastly, the hotel should not allow any drug-dealing activities within its premises".

The study of Hashim et al. (as cited in Salleh, Hamid, Hashim, \& Omain, 2014)) viewed ICH from marketing activities direction, and he argued that "destination marketing organizations and hotels could improve their marketing efforts by presenting more Islamic information on their Web sites". Rosenberg \& Choufany (2009)based on discussion with industrial practitioners classified the features of an ICH into three broad categories. These are the operations, design and interiors, and financial requirements. However, Salleh, Hamid, Hashim, \& Omain (2014)believed that the guidelines neglect the daily needs of Muslim travelers, which include performing daily prayer. Bakr (as cited in Stephenson, Russell, \& Edgar 2010)described the feature of Islamic hotels to include:

"traditional uniforms for hotel staff, dress code for female staff, markers indicating the direction of Mecca, female and male prayer rooms, prayer mats and prayer beds "tasbi", halal food with no pork, conservative television channels, art that does not depict the human form, and beds and plumbing placed away from facing Mecca. Furthermore, finance used to operate the hotel should be compliant to Shari'ah regulations and the hotel owner must contribute a proportion of revenue to Zakat (chartable acts) (Stephenson, Russell, \& Edgar 2010).

The work according to Salleh, Hamid, Hashim, \& Omain (2014)though provided broad procedures which focused on making the room interior in accordance with the Muslim requests and included management concept but "overlooks the entertainment and recreational facilities in accordance to the Shariah law, which are important to meet the needs of hotel guests". Henderson (2010)suggested a set attributes for the ICH which he believed are the "commonly accepted and have implications for operations as well as development and financing". The attributes contain:

i. No alcohol to be served or consumed on the premises

ii. Halal foods (slaughtered in the name of Allah and excluding all pork products and certain other items)

iii. Quran, prayer mats and arrows indicating the direction of Mecca in every room

iv. Beds and toilets positioned so as not to face the direction of Mecca

v. Bidets in bathrooms

vi. Prayer rooms

vii. Appropriate entertainment (no nightclubs or adult television channels)

viii. Predominantly Muslim staff

ix. Conservative staff dress

$\mathrm{x}$. Separate recreational facilities for men and women 
xi. All female floors

xii. Guest dress code

xiii. Islamic funding

However, Salleh, Hamid, Hashim, \& Omain (2014) described the attributes as "extremely general and overlooks the management element in $\mathrm{SCH}^{\prime \prime}$.

Nevertheless, despite the scanty work and lack of no established model, a set of general requirements and characteristics a hotel must meet to be an Islamic Compliant Hotel was adopted among some Muslim writers, researchers, academicians as well as industry practitioner. These characteristics according from the literatures can be classified as below based on the hotel operations.

Food, Drink and Kitchen

i. No alcohol to be served or consumed on the premises.

ii. Halal food (slaughtered in the name of Allah and excluding all pork products and certain other items). Daily Operations

i. Guest dress code must be posted at the hotel entrance or lobby.

ii. $\quad$ Art not depict human or animal form. Design for basic Needs

i. Quran prayer mats and arrows indicating the direction of Mecca in every room.

ii. $\quad$ Beds and toilets positioned so as not to be faced the direction of Mecca.

iii. All female floors for certain floor which separate them from floors for male and family.

iv. Copied of Quran or Quran with translation in every hotel room.

v. $\quad$ Printed prayer schedule in every hotel room Furnishing, Décor and Exterior

i. Must have prayer rooms either at the lobby or certain floor. The size of this room must be suitable enough to accommodate Muslim for congregation prayer at one time.

ii. Bidets in bathrooms to accommodate Muslim for ablution and any other activities related to religion.

iii. Separate recreational facilities for men and women including swimming pool, gym, spa etc. Entertainment

i. Appropriate entertainment (no nightclubs or adult television channels).

ii. Music background such as Quran recitation or nasyid and seek copyright permission for music.

iii. Shop selling Islamic related products such as Islamic books, CDs, Islamic attire, halal food and beverages or any other products that can be deemed as Islamic. Advertisement

i. Information on web Financial and Accounting

i. Islamic funding (hotel financed through Islamic financial instruments). Staffing and Personnel

i. Predominantly Muslim staff.

ii. Islamic staff dress code requirements.

iii. Akhlaq-trained staff.

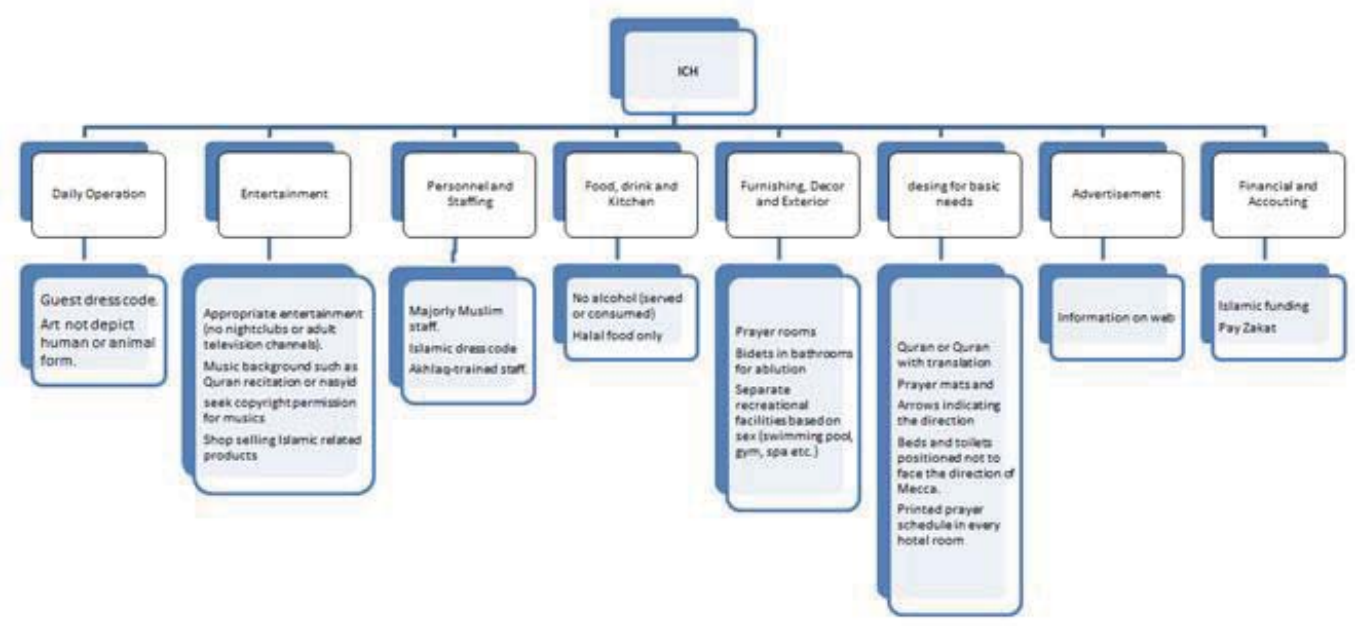

Adopted from Henderson(2010) and Hotel operations 


\section{Hospitality Services in Some Selected Hotels in Malaysia}

De Palma Hotel, Ampang offered halal restaurants, prayer rooms for the five daily prayers and a full time imam who leads the prayers. The Friday Prayers is also conducted in its surau weekly. It's one of the leading SCH in Malaysia. Therefore the $\mathrm{SCH}$ features in this hotel cover hotel operation, lodging

The Islamic floor at level 6 is mainly dedicated for Muslim guests and it characterizes Muslim-friendly service offered to Muslim travellers. On this floor, Muslim-friendly services offered include prayer room, direction of Qiblat in each room, prayer veils, Quran, Yassin and hand bidet in the toilet for ablution. Every prayer time the Azan will also be heard in the rooms. In addition, this hotel has a large prayer room with a full-time Imam to lead daily prayers and Friday prayers. De Palma hotel Ampang is the only hotel which is allowed to conduct Friday prayers. The prayer rooms accommodate a congregation of 1200- 2000 people includes staff and also joined by public. (Sahida et al., 2011)

They also provide $\mathrm{SCH}$ characteristics in related to personnel, halal food, drink and kitchen.

For the Muslim female staff, it is compulsory for them to wear Muslim costumes which cover the aurat. It is also compulsory for all the Muslim staff to pray during prayer time. As a Muslim-friendly service hotel, De Palma also provides halal food in their hotel restaurants and the restaurants are certified halal by Selangor Islamic Religious Department. In addition, the hotel also provides services for conference and business meeting package that comply with halal requirements such as offering the doa recital by the Iman and provision of zam-zam water and dates at the opening of meetings. Moreover, the hotel also conducts special religious classes on Al-Quran recital, Qiamullail and Tazkirah programs for hotel guest and staff in order to improve their religious knowledge. (Sahida et al., 2011)

PNB Darby Park Executive Suites is situated in KLCC is a hotel in Kuala Lumpur. It provides lodging services and according to Samori \& Abd Rahman (2013) has some elements of Islamic hotel. The features of SCH in their hotel include financial and accounting features, halal food and restaurant,

They did implement the Islamic financial system in their management and investment. They have two restaurants which all of the restaurants and café in their premise had certification of halal recognized by JAKIM. Apart from that, they also implemented Samak (clean off the najismughallazah) concept in the apartment kitchen when the tenancy duration period for non-Muslim tenant had been ceased. This Suite also provides some family entertainment (karaoke room for family members) and other facilities which do not contradict with Islamic principles. (Samori \& Abd Rahman, 2013)

The hotel also provided separate time allocation for swimming pool based on gender and disallowed alcoholic drinks

Furthermore, it also did not allow (disallows) customers to bring alcoholic beverages into the hotel premises. Other services to reinforce the Muslim-friendly for customers are to provide swimming pool facilities for male and female customers. Usually this separation is done when there was an arrival of summer tourists from the Middle East and it is done by the fraction of time to use the swimming pool.(Samori \& Abd Rahman, 2013)

Grand BlueWave Hotel Shah Alam is a 5 star hotel that provides Halal food in all restaurants with an authorization from JAKIM (Department of Islamic Development Malaysia) and JAIS (Selangor Islamic Religious Department). The restaurants do not alcohol drinks. The hotel has dedicated floor for women, Al-Qur'an is given to guest based on request, qiblat signage displayed in all rooms, separate male and female spa.

...there was no alcoholic beverages, halal food services and provides qiblat for prayer in each room. In addition, Halal Certification from JAKIM (Malaysia Department of Islamic Development) was also displayed in each room. All of 341 hotel room was provided by qiblat signage and a prayer mat. Hotel guest could make a request on Al-Quran it will be delivered upon request. Apart from that, it is interesting to note that, this hotel provides specialty for women visitors where there are given priority to occupy at level 17 of this hotel. Since this level is specified for women per se. Only the customers who have the special access card can enter the pavement floor and the hotel has installed a special door with its own security system to prevent men from entering this level. In addition, this hotel also offers an indoor pool facility, gymnasium for women. In order to facilitate women customers, specific time had been allocated to use this facility that is one hour for each day starting at 2.30 pm. (Kosmo, 2013 as cited in Samori \& Abd Rahman, 2013) 


\begin{tabular}{|c|c|c|c|c|c|c|c|c|c|c|}
\hline & SCH Features/ Hotel & \begin{tabular}{c|} 
De \\
Palma \\
Hotel \\
\end{tabular} & $\begin{array}{c}\text { PNB Darby } \\
\text { Park Executive } \\
\text { Suites } \\
\end{array}$ & $\begin{array}{c}\text { Grand } \\
\text { BlueWave } \\
\text { Hotel }\end{array}$ & $\begin{array}{l}\text { Grand } \\
\text { Seasons }\end{array}$ & $\begin{array}{l}\text { Sunway } \\
\text { Putra } \\
\text { Hotel } \\
\end{array}$ & \begin{tabular}{c|} 
Grand Lexis \\
Pork \\
Dickson \\
\end{tabular} & $\begin{array}{l}\text { The Legend } \\
\text { Cherrating } \\
\text { Beach Resort } \\
\end{array}$ & $\begin{array}{c}\text { Lexis Pork } \\
\text { Dickson }\end{array}$ & $\begin{array}{c}\text { Seri } \\
\text { Pacific } \\
\text { Hotel }\end{array}$ \\
\hline 1 & $\begin{array}{l}\text { Prayer direction marked } \\
\text { in the rooms }\end{array}$ & & & AVA & AVA & AVA & AVA & AVA & AVA & AVA \\
\hline 2 & Halal Certified Kitchen & & & AVA & AVA & AVA & AVA & AVA & AVA & AVA \\
\hline 3 & \begin{tabular}{|l|} 
Halal foods available at \\
walking distance
\end{tabular} & & & AVA & AVA & AVA & & AVA & AVA & AVA \\
\hline 4 & $\begin{array}{l}\text { Mosque at walking } \\
\text { distance }\end{array}$ & & & AVA & & AVA & & & & AVA \\
\hline 5 & $\begin{array}{l}\text { Hand shower/Bidets in } \\
\text { bathrooms }\end{array}$ & & & AVA & AVA & AVA & AVA & AVA & AVA & AVA \\
\hline 6 & $\begin{array}{l}\text { No adult TV channels in } \\
\text { the room }\end{array}$ & & & AVA & AVA & AVA & AVA & AVA & AVA & AVA \\
\hline 7 & $\begin{array}{l}\text { No part of a gambling } \\
\text { resort }\end{array}$ & & & AVA & AVA & AVA & AVA & AVA & AVA & AVA \\
\hline 8 & $\begin{array}{l}\text { Halal Certified } \\
\text { Restaurant } \\
\end{array}$ & & & AVA & & & & & & \\
\hline 9 & $\begin{array}{l}\text { No alcohol served in } \\
\text { the hotel }\end{array}$ & & & AVA & & & & & & \\
\hline 10 & $\begin{array}{l}\text { No discotheque (Night } \\
\text { club) }\end{array}$ & & & AVA & & & & & & \\
\hline 11 & $\begin{array}{l}\text { Dedicated space for } \\
\text { prayer }\end{array}$ & & & AVA & AVA & & AVA & & AVA & AVA \\
\hline 12 & Prayer time table & & & AVAR & AVAR & AVAR & AVAR & AVAR & AVAR & AVAR \\
\hline 13 & List of Masjid nearby & & & AVAR & AVAR & AVAR & AVAR & AVAR & AVAR & AVAR \\
\hline 14 & Prayer mat & & & AVAR & AVAR & AVAR & AVAR & AVAR & AVAR & AVAR \\
\hline 15 & Female Prayer dress & & & AVAR & AVAR & AVAR & AVAR & AVAR & AVAR & AVAR \\
\hline 16 & List of Halal restaurants & $\mathrm{AVA}^{*}$ & AVA* $^{*}$ & AVAR & AVAR & AVAR & AVAR & AVAR & AVAR & AVAR \\
\hline 17 & $\begin{array}{l}\text { Room service has halal } \\
\text { options }\end{array}$ & & & AVA & AVA & AVA & AVA & AVA & AVA & AVA \\
\hline 18 & $\begin{array}{l}\text { Arrangement of Iftar } \\
\text { and Sahoor }\end{array}$ & & & AVAR & AVAR & AVAR & AVAR & AVAR & AVAR & AVAR \\
\hline 19 & $\begin{array}{l}\text { Has separate } \\
\text { Male/Female Spa }\end{array}$ & & & AVA & & & & & AVA & \\
\hline 20 & Halal banquet & & & AVAR & & & & & & \\
\hline 21 & $\begin{array}{l}\text { Quran available in the } \\
\text { room }\end{array}$ & & & AVA & & & & & & \\
\hline
\end{tabular}

Meaning of Terms: AVA - Available on Request; AVAR - Available on Request; NAVA - Not Available

\section{References}

Barrows, C. W., \& Powers, T. (2009). Introduction to the Hospitality Industry (Seventh.). John Wiley \& Sons Inc.

Brotherton, B., \& Wood, R. C. (2000). Hospitality and Hospitality Management. In C. Lashley \& A. Morrison (Eds.), In Search of Hospitality, Theoretical Perspectives and Debates (First., pp. 134 - 156). Butterworth-Heinemann.

Calvo, A. M. M. (2013). Junot Díaz's "Otravida, Otravez" and Hospitalia: the workings of Hostile Hospitality. Journal of Modern Literature, 37(1), $107-123$.

Henderson, J. C. (2010). Sharia-compliant hotels. Tourism and Hospitality Research, 10(3), 246-254. doi:10.1057/thr.2010.3

Khan, R. R. (2012, November). Hospitality in Islam. Hiba - Muslim Lifestyle Magazine. Retrieved from http://www.hibamagazine.com /category/past-issues/hospitality-in-islam/

Lashley, C. (2000). Towards a theoretical understanding. In C. Lashley \& A. Morrison (Eds.), In Search of Hospitality, Theoretical Perspectives and Debates (pp. 1-17). Butterworth-Heinemann.

Lashley, C., Lynch, P., \& Morrison, A. (2007). Hospitality: An Introduction. In C. Lashley, P. Lynch, \& A. Morrison (Eds.), Hospitality A social Lens (First Edit., p. 2007). Elsevier Ltd.

Md Salleh, N. Z., Abdul Hamid, A. B., Hashim, N. H., \& Omain, S. Z. (2014). The Practice of Shariah-Compliant Hotel in Malaysia. International Journal of Trade, Economics and Finance, 5(1), 26-30. doi:10.7763/IJTEF.2014.V5.335

Meehan, S. (2012). Hospitality in Islam: The Joy of Honoring Guests. Onislam. Retrieved June 05, 2014, from http://www.onislam.ne t/english/reading-islam/understanding-islam/ethics-and-values/460191-hospitality-in-islam-the-joy-of-honoringothers.html?Values=

O'Connor, D. (2005). Towards a new interpretation of "hospitality." International Journal of Contemporary Hospitality Management, 17(3), 267-271. doi:10.1108/09596110510591954

Ramli, N. (2009). HALAL TOURISM : THE WAY FORWARD. In IIUM-2009. IREP.

Razalli, M. R., Abdullah, S., \& Hassan, M. G. (2012). Developing a Model for Islamic Hotels : Evaluating Opportunities and Challenges, 91-95. 
Rosenberg, P., \& Choufany, H. M. (2009). Spiritual Lodging - the Sharia Compliant Hotel Concept. HVS Global Hospitality ServicesDubai, (April).

Sahida, W., Ab Rahman, S., Awang, K., \& Che Man, Y. (2011). The Implementation of Shariah Compliance Concept Hotel : De Palma Hotel Ampang, Malaysia. In Internantional Conference on Humanities, Historical and Social Sciences (Vol. 17, pp. 138-142).

Samori, Z., \& Abd Rahman, F. (2013). Establishing Shariah Compliant Hotels in Malaysia: Identifying Opportunities, Exploring Challenges. West East Journal of Social Science, 2(2), 95-108.

Stephenson, M. L., Russell, K. A., \& Edgar, D. (2010). Islamic hospitality in the UAE: indigenization of products and human capital. Journal of Islamic Marketing, 1(1), 9-24. doi:10.1108/17590831011026196 